\title{
Synthesis and Anti-tumor Activity Study of Shogaol
}

\section{Analogues}

\author{
Song Lei, Duan Yu, Xu Da and Mao Yu \\ College of Pharmacy, Southwest Minzu University, No. 16, Duan 4, Yihuan Road, Chengdu 610041, P. R. China
}

\begin{abstract}
As one of the largest global public health problems, cancer greatly endangers human health. Researchers have been committed to discovering anticancer drugs with high efficiency and low toxicity. Shogaol, a kind of ingredient from ginger with high anti-tumor activity, has attracted our attention. This study was an investigation on the composition and structure-activity relationship of different analogues of shogaol, with the purpose to screen for shogaol compounds which had higher anti-tumor activity and could be easily synthesized. We chose zingerone as the starting material to synthesize shogaol through four-step reactions without protective group, as a result, 31 analogues were synthesized for anti-tumor activity detect. The biological test results showed that: the missing of the unsaturated ketone and the phenolic hydroxyl group reduced the anti-tumor activity of shogaol; the site of phenolic hydroxyl had no significant influence on the anti-tumor activity, the indicating that the larger the steric hindrance of substituent, the lower the activity, but the higher the activity of cyclobutyl substituted derivatives.
\end{abstract}

Key words: Shogaol, synthesis, analogues, anti-tumor activity.

\section{Introduction}

Cancer is among the greatest threat to global public health and only second to cardiovascular diseases in terms of harm. In a modernizing society and under adverse environmental impact, the prevalence of cancer has been rising. In 2000 there were 10.1 million newly diagnosed cancer patients worldwide, with 6.2 million deaths [1]. By 2008, the figures climbed to 12.66 million and 7.56 million, respectively [2]. It is estimated that, by 2015, there will be 15 million newly diagnosed cancer patients [3]. What aggravates the situation is that cancer is no longer confined to the developed countries. In 2008, the newly diagnosed cancer cases in the developing countries accounted for $56 \%$ of the total [2]. While $80 \%$ of the cancer cases were found in low to moderate-income countries in 2009 , it is predicted that by 2015, about 9 million people in the developing countries will die from cancer [3]. To cope with the huge burden brought by cancer, looking for cheap and

Corresponding author: Song Lei, doctor of science, research fields: medicinal chemistry. available anti-tumor drugs becomes increasingly urgent.

Shogaol (Fig. 1) is generated from gingerol by removing one molecule of water during storage or under heating. Shogaol is more pungent and displays a wider range of physiological activities, especially in the anti-tumor field [4]. 6-Shogaol can be used to treat gastric cancer [5], oral cancer [6], liver cancer [7], lung cancer [8] and colorectal cancer [9]. 6-Shogaol induces the apoptosis of liver cancer cells with low differentiation and P53 mutation (featured by high expression of drug resistance genes MDR-1 and Bcl-2) and enhances the sensitivity to chemotherapy [10]. Study has shown preliminarily that 6-shogaol is effective against acute leukemia. The phosphorylation of eIF $2 \alpha$ and the subsequent caspase-dependent degradation are closely associated with the pro-apoptotic effect. This may be the basis for the use of 6-shogaol to treat hematological malignancies [11].

This study was an investigation on the chemical properties of shogaol as the anti-tumor agent, including its composition and the structure-activity relationship, in an attempt to screen for shogaol 
compounds which had higher activity and can be easily synthesized.

\section{Synthesis of shogaol}

(1) Researchers are devoted to the synthesis of shogaol to expand its application as a bioactive agent. In 1976 Mukaiyama [12] produced gingerol through the condensation of silyl enol ethers from zingerone and aliphatic aldehydes, then shogaol was obtained through further dehydration of gingerol in the presence of acid (Fig. 2). This strategy was widely used in many situations [13]. Then in 1990, Sattar applied Horner-Wadsworth-Emmons reaction to prepare shogaol from vanillin [14] (Fig. 3). In 2010, Mase using vanillin as the starting material, synthesized shogaol through the Mannich-type condensation of the ketone donor with the aldehyde acceptor through the iminium cation intermediate reaction catalyzed by DIMCARB (dimethylammonium dimethylcarbamate) with aliphatic aldehydes [15] (Fig. 4).

All the above mentioned pathways successfully

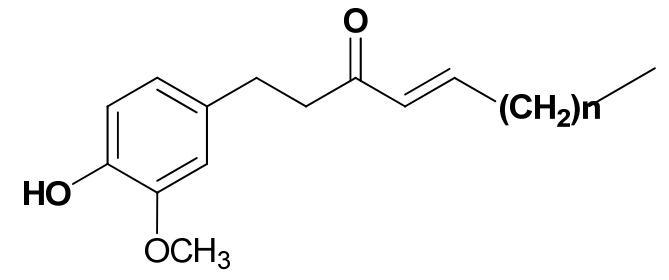

1. $\mathrm{n}=4$, 6- shogaol

$2 \mathrm{n}=6,8$ - shogaol

3. $\mathrm{n}=8$, 10-shogaol

Fig. 1 Structural formula of shogaol.<smiles>C=C(C)O[Si](C)(C)C=CC(=O)C=Cc1ccc(O)c(OC)c1</smiles>

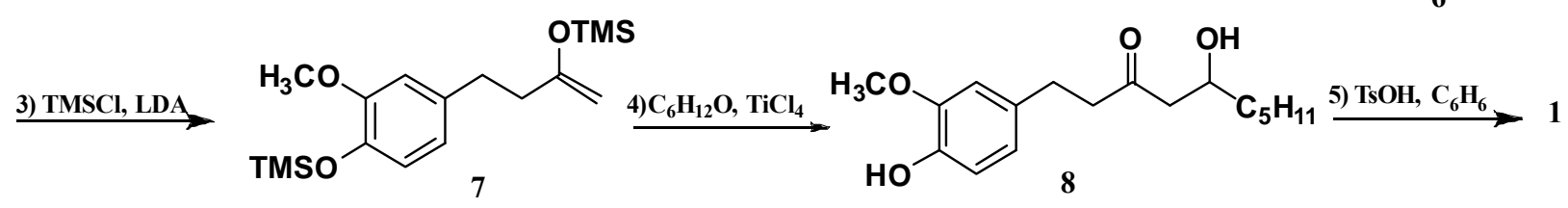

Fig. 2 Synthesis of shogaol by Teruaki Mukaiyama.

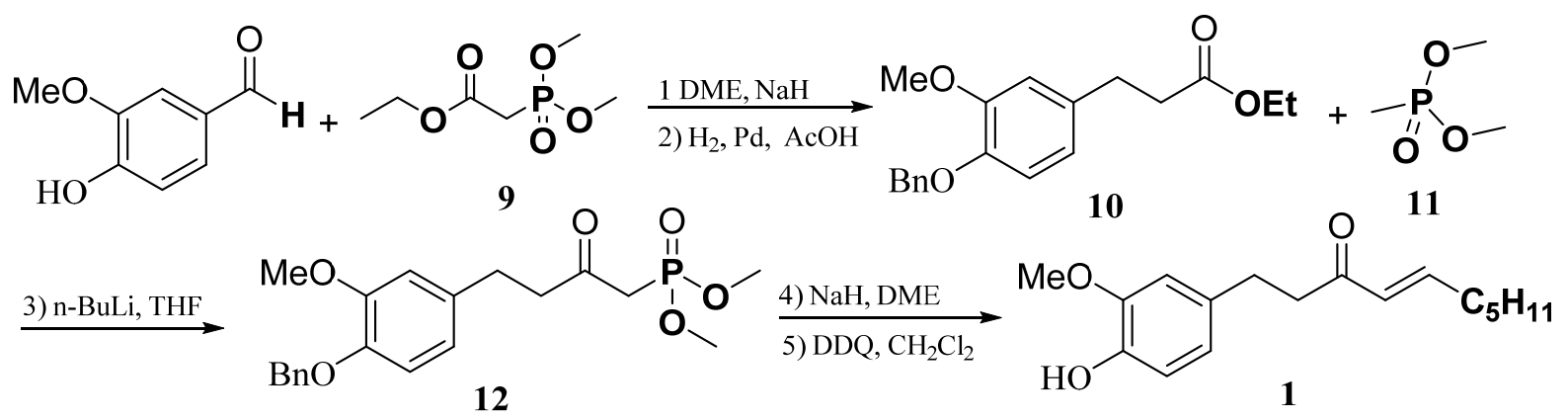

Fig. 3 Synthesis of shogaol by Sattar.<smiles>COc1cc(C=O)ccc1O</smiles>

Fig. 4 Synthesis of shogaol by Nobuyuki Mase. 
synthesized shogaol by some expensive reagents or under the conditions of low temperature, water and oxygen free, in this paper we describe a cheaper and easier handle synthetic pathway.

(2) Synthetic strategy 1

Drawing inspirations from Nobuyuki Mase's pathway, we attempted to directly prepare shogaol by condensation of zingerone and aliphatic aldehydes (e.g., hexaldehyde), using cheaper catalysts. First sodium hydroxide was chosen as the catalyst. In one equivalent of sodium hydroxide in methanol, zingerone was consumed rapidly with the appearance of 3 products, which were isolated by silica gel column chromatography. The primary product came from the condensation of hexaldehyde itself (14); the secondary product was 6-shogaol, the target product; the minor product was isomeric 6-shogaol (13) [16] (Fig. 5). The proportion of 6-shogaol (6S) to isomeric 6-shogaol (iso-6S) was 55:45, which indicated the activity of methyl group and methylene group adjacent to carbonyl group was comparable. To raise the proportion of $6 \mathrm{~S}$, the conditions were optimized, including lowering the temperature and using larger-volume catalysts (e.g., triethylamine, pyridine and DBU), but the proportion of iso-6S was still high. Moreover, due to structural similarities between the $6 \mathrm{~S}$ and iso-6S, it could be hardly separated by column chromatography which was not suitably for scale synthesis. Therefore, a second synthetic strategy was proposed.

(3) Synthetic strategy 2

The retrosynthetic analysis of strategy 2 was as follows (Fig. 6): formylated 6S was first prepared by Knoevenagel condensation reaction between formylated zingerone (7) and aliphatic aldehyde. Then $6 \mathrm{~S}$, the target product, was obtained by decarboxylation [17]. Formylated zingerone (7) can be prepared from zingerone.

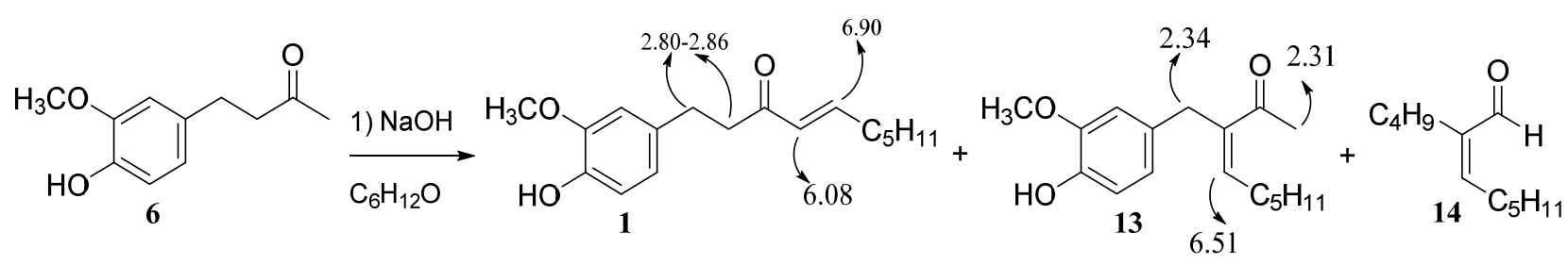

Fig. 5 Synthesis of Shogaol (strategy 1).

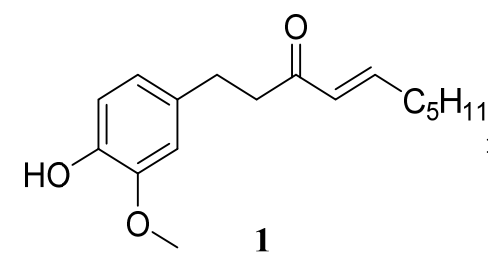

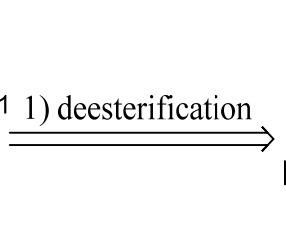<smiles>CCCCCCCCCCCCCCC(=O)C(=CCc1ccc(O)c(OC)c1)C(=O)OCC</smiles>

2) knoevenagel reaction

15<smiles>C#CCCCCCC(=O)CC(=O)OCC</smiles><smiles>COc1cc(CCC(C)=O)ccc1O</smiles>
4) hydrogenation 5<smiles>C#CCOC(=O)CC(=O)/C=C/c1ccc(O)c(OC)c1</smiles>

Fig. 6 Retrosynthetic analysis of $6 \mathrm{~S}$. 
Formylated zingerone (7) was first tried to be synthesized from zingerone by formylation. Unfortunately, the products were very complex even we tried various conditions and the target product was hard to get. Therefore dehydrozingerone was used as the starting material. Under diethyl carbonate/sodium hydride system, the raw material was soon exhausted, and primary product appeared which was identified as the target formylated dehydrozingerone (17). Formylated dehydrozingerone (17) was then selective hydrogenated to formylated zingerone (7) by Raney Ni. When the important intermediate 7 was in hand, next we tried the key transformation to shogaol by knoevenagel condensation reaction and decarboxylation in one pot. As shown in Table 1, first, under classic knoevenagel condensation reaction (piperidine/EtOH), there is no shogaol appeared but only knoevenagel condensation product. Then we raised the reaction temperature to reflux, the products were very complicated the target was less than $10 \%$. Based on the above experience we changed the piperidine to sodium hydroxide and made the reaction proceed in two stages: the initial temperature was $0{ }^{\circ} \mathrm{C}$, after the raw material was consumed out the temperature was $80{ }^{\circ} \mathrm{C}$. The way of adding hexaldehyde was also changed: if hexaldehyde was added in one time, the amount of (14) was very high, if the hexaldehyde was first dissolved in some solvent and the mixture was added into the reaction by syringe in a few minutes, (14) would greatly reduce. Besides, iso-6S was absent in the product. Through the above optimization, 6S was obtained from zingerone by 65\% yield (Fig. 7).

(4) Synthesis of 6S analogues

In order investigate the SAR of shogaol on cancer cell, in this study we synthesized a variety of $6 \mathrm{~S}$ analogues (Table 2).

The side chain of shogaols was regarded to play an important role for the shogaols' bioactivity [13], so three types of 6S analogues were prepared with aromatic, branched and circular side chains (19-30) (Fig. 8).

Phenolic hydroxyl group is regarded as having free radical clearing ability and antioxidative ability and

Table 1 Synthesis of 6S.

\begin{tabular}{lllll}
\hline Entry & Hexaldehyde & Condition & $1^{\mathrm{c}}$ & $14^{\mathrm{d}}$ \\
\hline 1 & $0.9^{\mathrm{a}}$ & $\mathrm{NaOH}, 0{ }^{\circ} \mathrm{C}, 1 \mathrm{~h}$; reflux, $1 \mathrm{~h}$ & $70 \%$ & $5 \%$ \\
2 & $0.9^{\mathrm{b}}$ & $\mathrm{NaOH}, 0{ }^{\circ} \mathrm{C}, 1 \mathrm{~h}$; reflux, $1 \mathrm{~h}$ & $60 \%$ & $15 \%$ \\
3 & $0.9^{\mathrm{a}}$ & $\mathrm{NaOH}$, relux, $1 \mathrm{~h}$ & $\mathrm{C}$ & - \\
4 & $1.2^{\mathrm{a}}$ & $\mathrm{NaOH}, 0{ }^{\circ} \mathrm{C}, 1 \mathrm{~h}$; reflux, $1 \mathrm{~h}$ & $75 \%$ & $15 \%$ \\
5 & $1.2^{\mathrm{b}}$ & $\mathrm{NaOH}, 0{ }^{\circ} \mathrm{C}, 1 \mathrm{~h}$; reflux, $1 \mathrm{~h}$ & $70 \%$ & $20 \%$ \\
6 & $1.2^{\mathrm{a}}$ & $\mathrm{NaOH}$, relux, $1 \mathrm{~h}$ & Complicated & - \\
\hline
\end{tabular}

a the hexaldehyde was dissolved in THF and added via syringe in $0.5 \mathrm{~h} ;{ }^{b}$ the hexaldehyde was added in one time; ${ }^{\mathrm{c}}$ calculated by zingerone; ${ }^{\mathrm{d}}$ calculated by hexaldehyde.

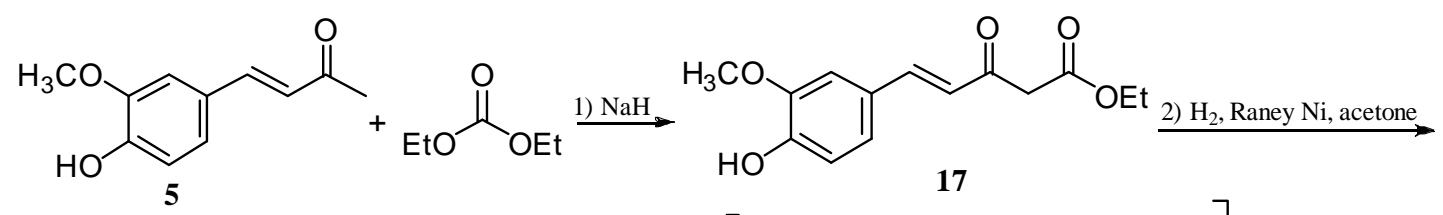<smiles>CCCCCCCCCCCCCCCC(=O)OCC</smiles>

Fig. 7 Synthesis of $6 \mathrm{~S}$. 
Table 2 Synthesis of 6S analogues.

\begin{tabular}{llllllllllll}
\hline $\mathrm{NO}$ & $\mathrm{R}_{1}$ & $\mathrm{R}_{2}$ & Yield & $\mathrm{NO}$ & $\mathrm{R}_{1}$ & $\mathrm{R}_{2}$ & Yield & $\mathrm{NO}$ & $\mathrm{R}_{1}$ & $\mathrm{R}_{2}$ & Yield \\
\hline 19 & $1 \mathrm{a}$ & $2 \mathrm{a}$ & $60 \%$ & 31 & $1 \mathrm{~b}$ & $2 \mathrm{a}$ & $62 \%$ & 39 & $1 \mathrm{c}$ & $2 \mathrm{a}$ & $60 \%$ \\
20 & $1 \mathrm{a}$ & $2 \mathrm{~b}$ & $65 \%$ & 32 & $1 \mathrm{~b}$ & $2 \mathrm{~b}$ & $65 \%$ & 40 & $1 \mathrm{c}$ & $2 \mathrm{~b}$ & $63 \%$ \\
21 & $1 \mathrm{a}$ & $2 \mathrm{c}$ & $68 \%$ & 33 & $1 \mathrm{~b}$ & $2 \mathrm{c}$ & $66 \%$ & 41 & $1 \mathrm{c}$ & $2 \mathrm{c}$ & $66 \%$ \\
22 & $1 \mathrm{a}$ & $2 \mathrm{~d}$ & $68 \%$ & 34 & $1 \mathrm{~b}$ & $2 \mathrm{~d}$ & $65 \%$ & 42 & $1 \mathrm{c}$ & $2 \mathrm{~d}$ & $68 \%$ \\
23 & $1 \mathrm{a}$ & $2 \mathrm{e}$ & $70 \%$ & 35 & $1 \mathrm{~b}$ & $2 \mathrm{e}$ & $73 \%$ & 43 & $1 \mathrm{c}$ & $2 \mathrm{e}$ & $72 \%$ \\
24 & $1 \mathrm{a}$ & $2 \mathrm{f}$ & $55 \%$ & 36 & $1 \mathrm{~b}$ & $2 \mathrm{f}$ & $58 \%$ & 44 & $1 \mathrm{c}$ & $2 \mathrm{f}$ & $53 \%$ \\
25 & $1 \mathrm{a}$ & $2 \mathrm{~g}$ & $50 \%$ & 37 & $1 \mathrm{~b}$ & $2 \mathrm{~g}$ & $55 \%$ & 45 & $1 \mathrm{c}$ & $2 \mathrm{~g}$ & $55 \%$ \\
26 & $1 \mathrm{a}$ & $2 \mathrm{~h}$ & $53 \%$ & 38 & $1 \mathrm{~b}$ & $2 \mathrm{~h}$ & $55 \%$ & 46 & $1 \mathrm{c}$ & $2 \mathrm{~h}$ & $55 \%$ \\
27 & $1 \mathrm{a}$ & $2 \mathrm{i}$ & $70 \%$ & & & & & 47 & & & $95 \%$ \\
28 & $1 \mathrm{a}$ & $2 \mathrm{j}$ & $72 \%$ & & & & & 48 & & & $98 \%$ \\
29 & $1 \mathrm{a}$ & $2 \mathrm{k}$ & $75 \%$ & & & & & 49 & & & $98 \%$ \\
30 & $1 \mathrm{a}$ & $2 \mathrm{l}$ & $70 \%$ & & & & & & & & \\
\hline
\end{tabular}

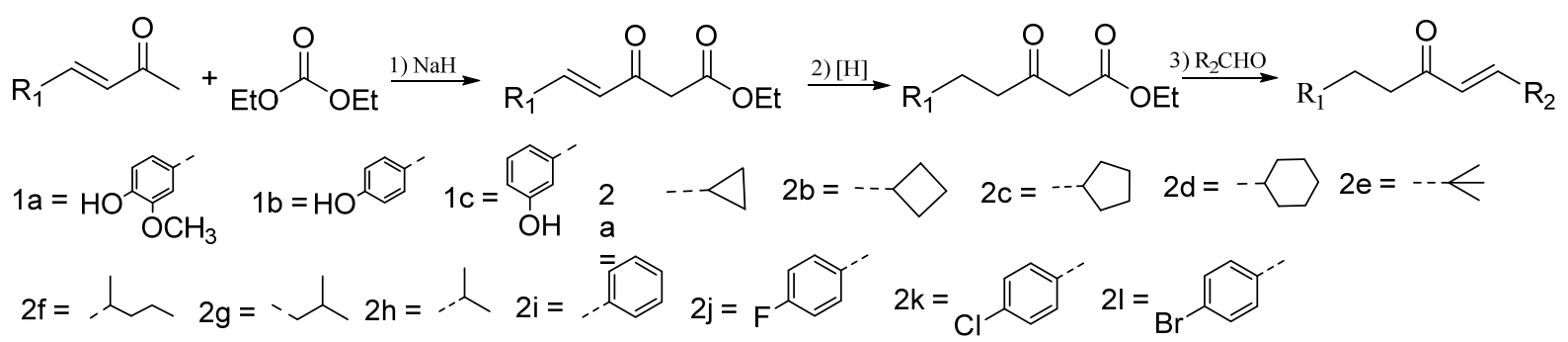

Fig. 8 General formula for synthesis of $6 \mathrm{~S}$ analogues.<smiles>CCCCCCCC=CC(=O)CCc1ccc(O)c(OC)c1</smiles>

$\underset{\text { 1) } \mathrm{H}_{2} \text {, Raney } \mathrm{Ni}}{\text { acetone,rt,1h }}$<smiles>CCCCCCCCCC(=O)CCc1ccc(O)c(OC)c1</smiles>

1<smiles>CCCCCCCC=CC(=O)CCc1ccc(O)c(OC)c1</smiles>

1) $\mathrm{H}_{2}$, Raney $\mathrm{Ni}$ THF or $\mathrm{CH}_{3} \mathrm{OH}, \mathrm{rt}, 1 \mathrm{~h}$<smiles>CCCCCCCCC(=O)CCc1ccc(O)c(OC)c1</smiles>

47

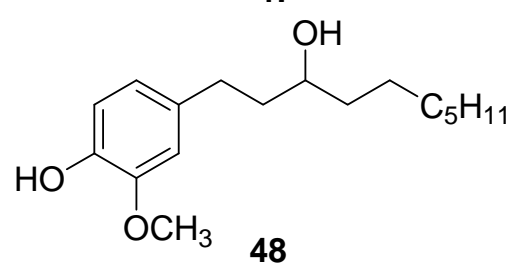

48<smiles>CCCCCCCCCC(=O)C=Cc1ccc(OC)c(OC)c1</smiles>

Fig. 9 Synthesis of $6 \mathrm{~S}$ analogues.

also an important structural domain with the anti-tumor effect. $6 \mathrm{~S}$ analogues $(31-46,49)$ were synthesized to examine the effect of phenolic hydroxyl group on bioactivity (Fig. 8). Derivative (49) was prepared by methylation of 6S in acetone (Fig. 9). $\alpha, \beta$-unsaturated ketone is considered the anti-tumor domain in many natural metabolites. By Michael addition with large molecules, $\alpha, \beta$-unsaturated ketone can induce endoplasmic reticulum stress and hence tumor cell death [18] or kill tumor cells by damaging 
the microtubules [19]. We synthesized the selective reductive compound (47) and the fully reductive compound (48) by hydrogenating in acetone or THF.

\section{In vitro Screening for Shogaol Derivatives with High Anti-tumor Activity}

Materials

a. Reagents

HeLa cervical cancer cells (ATCC medium), pancreatic cancer cells ASPC-1 and PANC-1 (Nanjing KeyGen Biotech Co., Ltd.), human umbilical vein endothelial cells HUVECs (ATCC medium). DMEM medium (Nanjing KeyGen Biotech Co., Ltd., for culturing pancreatic cancer cells, ATCC medium for culturing HUVECs), fetal bovine serum (GIBCO, USA), MTT solution (Sigma, USA), DMSO (Sinopharm Group Co., Ltd.), Matrigel (BD Corporation, USA). 6S was isolated at our laboratory. All $6 \mathrm{~S}$ analogues were prepared into $100 \mu \mathrm{M}$ stock solution using DMSO.

b. Equipments

Biosafety cabinet, cell incubator, microplate reader. c. Method

\section{MTT assay:}

Log phase cells were harvested, made into a cell suspension and inoculated to a 96-well plate at the density of 5,000 cells $/ \mathrm{mL}$ for $200 \mu \mathrm{L}$ per well. The cells were placed at $37{ }^{\circ} \mathrm{C}$ into a $5 \% \mathrm{CO}_{2}$ humidified incubator for $24 \mathrm{~h}$ and the drugs of different concentrations were added into the 96-well plate. MTT solution $(5 \mathrm{mg} / \mathrm{mL})$ was added into the 96 -well plate for $20 \mu \mathrm{L}$ per well and incubated at $37{ }^{\circ} \mathrm{C}$ for $4 \mathrm{~h}$. The supernatant was collected and $200 \mu \mathrm{L}$ DMSO was added into each well. The crystals were fully dissolved on a low-speed shaker for $10 \mathrm{~min}$. Absorbance was measured in each well using a microplate reader at $570 \mathrm{~nm}$. $\mathrm{IC}_{50}$ value was calculated using Graphpad software.

In vitro vascular lumen formation assay:

(1) A total of $50 \mu \mathrm{L}$ matrigel was thawed and added into the 96 -well plate precooled at $4{ }^{\circ} \mathrm{C}$ for curing at
$37{ }^{\circ} \mathrm{C}$ for $30 \mathrm{~min}$.

(2) Three groups were set up, namely, blank control group, negative control group and drug treatment group, with 5 replicates in each group. Into the blank control group $100 \mu \mathrm{L}$ of the culture medium containing $3 \times 10^{4}$ HUVECs was added. For the negative control group, $100 \mu \mathrm{L}$ of culture medium containing $3 \times 10^{4}$ HUVECs and DMOS was added. For the drug treatment group, the drug of different concentrations was added along with the culture medium containing $3 \times 10^{4}$ HUVECs.

(3) The plates were cultured at $37{ }^{\circ} \mathrm{C}$ in a $5 \% \mathrm{CO}_{2}$ incubator for $6 \mathrm{~h}$. Images were taken under the inverted microscope at $200 \times$ magnification.

Evaluation criteria: The effect of the drugs on vascular lumen formation was assessed by counting vascular lumens within the visual field. The more the vascular lumens, the greater the effect of the drugs on vascular lumen formation.

\section{Results}

\subsection{Effects of 65 and Its Analogues on Tumor Cell Proliferation}

As shown in Table 3, the reactivity of analogues with aromatic side chains was weaker than that of $6 \mathrm{~S}$ on Hela cells. The reactivity decreased with the reduction in electron cloud density of the benzene ring $(27<28<29<30)$. But this variation pattern did not apply to pancreatic cancer cells Aspc-1 and Panc-1.

Of 12 analogues with circular side chains (19-22, $31-34,39-42)$, the activity of analogues with cyclobutyl groups on the side chains $(20,32,40)$ was stronger compared to the other 6 derivatives. The activity of analogues with cyclohexyl groups on the side chain $(22,34,42)$ came next and resembled that of $6 \mathrm{~S}$. The activity of analogues with cyclopentyl groups on the side chains was weaker than that of $6 \mathrm{~S}$. The activity of analogues with cyclopropyl groups on the side chains $(19,31,39)$ was the lowest. In terms of activity, analogues with cyclopropyl groups $<$ analogues with cyclohexyl groups $<$ analogues with 
Table 3 Proliferation toxicity of $6 \mathrm{~S}$ analogues on Hela cells and $\mathrm{IC}_{50}(\mu \mathrm{M})$.

\begin{tabular}{llllllll}
\hline Comp. & Hela & Aspc-1 & Panc-1 & Comp. & Hela & Aspc-1 & Panc-1 \\
\hline 19 & $>80.0$ & 84.7 & 79.6 & 34 & 37.1 & 58.6 & 61.3 \\
20 & 10.0 & 34.3 & 24.9 & 35 & $>80$ & $>100$ & $>100$ \\
21 & 19.0 & 31.4 & 48.3 & 36 & 11.8 & 30.9 & 18.9 \\
22 & 20.0 & 48.8 & 60.0 & 37 & $>80$ & 38.3 & 43.0 \\
23 & 80.0 & $>100$ & $>100$ & 38 & 37.1 & 46.8 & 49.8 \\
24 & 30.0 & 43.4 & 52.1 & 39 & 38.5 & $>100$ & $>100$ \\
25 & 18.5 & 43.4 & 45.7 & 40 & 26.7 & 61.0 & 62.5 \\
26 & 25.0 & 31.8 & 60.0 & 41 & 21.8 & 36.5 & 42.7 \\
27 & 65.0 & 31.3 & 45.1 & 42 & 35.2 & 54.3 & 50.8 \\
28 & 45.2 & 42.0 & 47.1 & 43 & 60.0 & $>100$ & 88.8 \\
29 & 33.0 & 35.5 & 49.4 & 44 & 15.0 & 26.2 & 21.6 \\
30 & 20.8 & 39.3 & 37.9 & 45 & 20.2 & 40.0 & 49.2 \\
31 & 21.0 & $>100$ & $>100$ & 46 & 16.3 & 34.0 & 37.8 \\
32 & 19.4 & 51.9 & 51.5 & 47 & $>80$ & $>100$ & $>100$ \\
33 & 18.8 & 40.1 & 48.6 & 48 & $>80$ & $>100$ & $>100$ \\
1 & 15.0 & 34.2 & 40.7 & 49 & $>80$ & $>100$ & $>100$ \\
\hline
\end{tabular}

cyclopentyl groups $<$ analogues with cyclobutyl groups.

Of 12 analogues with branched side chains (23-26, $35-38,43-46)$, the activity of trimethylacetaldehyde derivatives $(23,35,43)$ on all three cell lines was weaker to that of $6 \mathrm{~S}$; the activities of other 9 analogues were comparable to that of $6 \mathrm{~S}$.

Comparison between analogues 19-26, 31-38 and 39-46 indicated no substantial difference in bioactivity with the same side chains, that is, the missing of methyl ether had no impact on bioactivity. Comparison between analogues 31-38 and 39-46 indicated that substitution of phenolic hydroxyl group at different positions also had limited impact on bioactivity. But after methyl etherification of phenolic hydroxyl group, the bioactivity of compound 48 greatly reduced, as opposed to no obvious impact from the position of substitution of phenolic hydroxyl group. The reason is probably that the methyl etherification of phenolic hydroxyl group results in the loss of free radical clearing ability and hence the decline of anti-tumor effects.

Compounds 47 and 48 , the products from the reduction of $6 \mathrm{~S}$, were almost ineffective against Hela, Aspc-1 and Panc- 1 cells based on $\mathrm{IC}_{50}$ value, probably due to the failure of Michael addition between the reduction products and the large molecules inside the organisms.

Compared with pancreatic cancer cells ASPC-1 and PANC-1, Hela cells were more sensitive to $6 \mathrm{~S}$, indicating different working mechanism of $6 \mathrm{~S}$ on the three cell lines.

\subsection{Effects of 6S Analogues on the Proliferation of HUVECs and Vascular Lumen Formation}

The proliferation toxicity of $50 \mu \mathrm{M} 6 \mathrm{~S}$ analogues on HUVECs was assessed using MTT assay. The results showed that the toxicity of compounds $23,35,32,43$, 39 and 51 on HUVECs was smallest at $50 \mu \mathrm{M}$ concentration (Fig. 10). These 6 compounds were further tested in vascular lumen formation experiment.

The 96-well plate was coated with $50 \mu \mathrm{L}$ Matrigel, and $100 \mu \mathrm{L}$ of the culture medium containing the drugs, $3 \times 10^{4}$ HUVECs and DMSO was added. After the plate was placed at $37{ }^{\circ} \mathrm{C}$ in a $5 \% \mathrm{CO}_{2}$ incubator for $6 \mathrm{~h}$, vascular lumen formation was observed under the inverted fluorescence microscope. The photos are shown below (Fig. 11). All six compounds tested did not inhibit vascular lumen formation. In other words, they had neither cytotoxicity nor proliferation toxicity on HUVECs. 


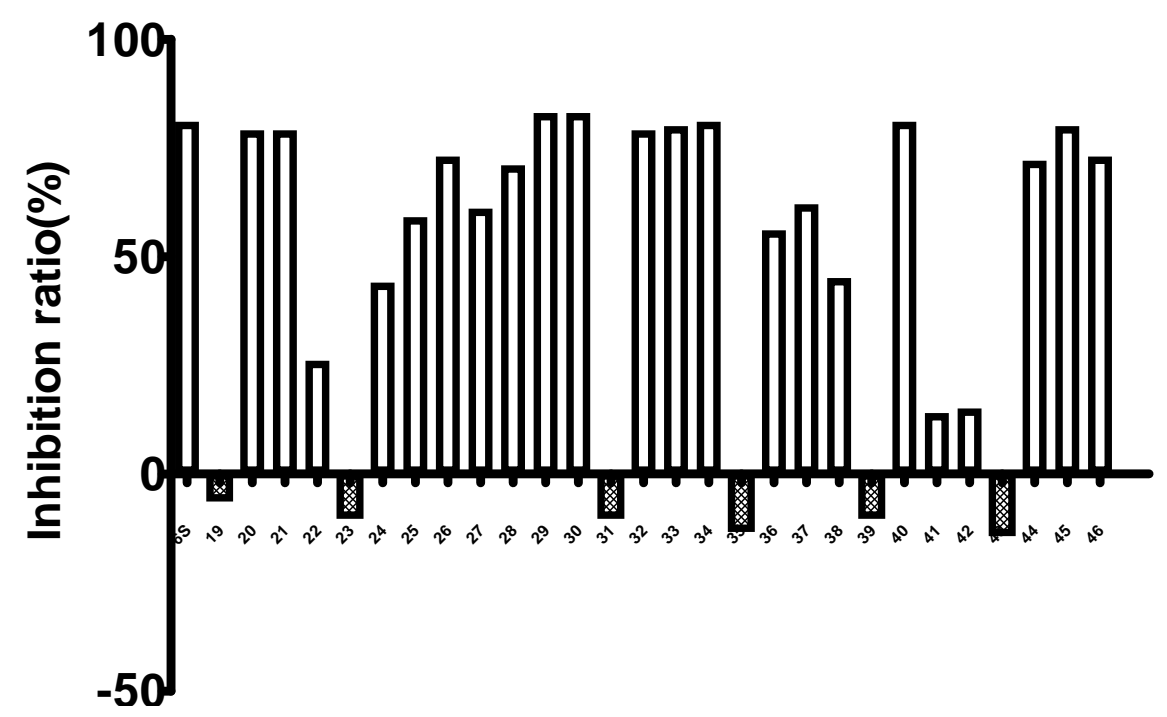

Fig. 10 Screening for 6 S analogues with no proliferation toxicity on HUVECs by MTT assay.

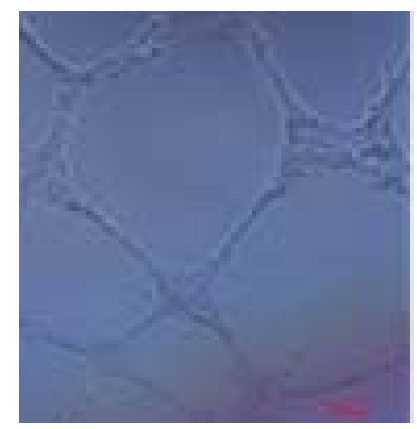

(a) Blank control

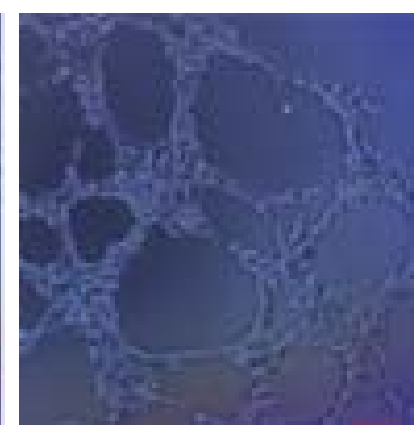

(b) 23

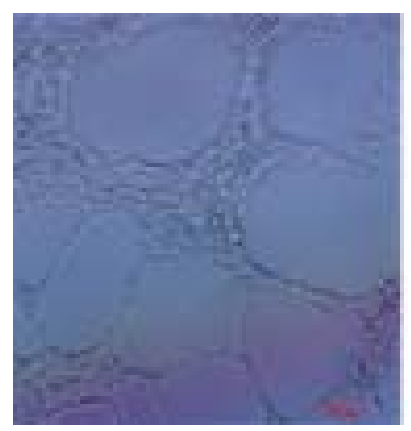

(c) 35

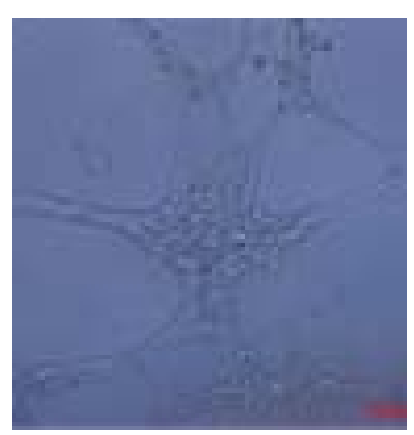

(d) 32

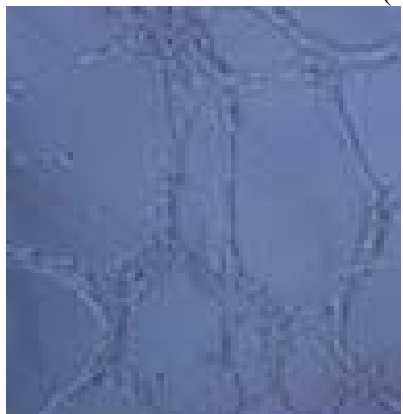

(e) 43

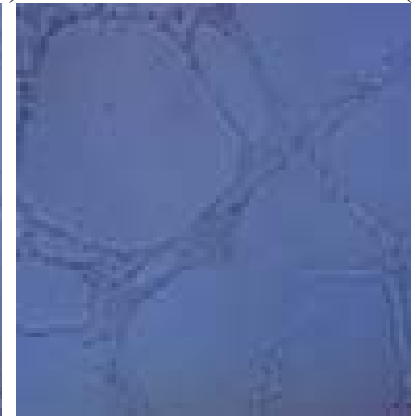

(f) 39

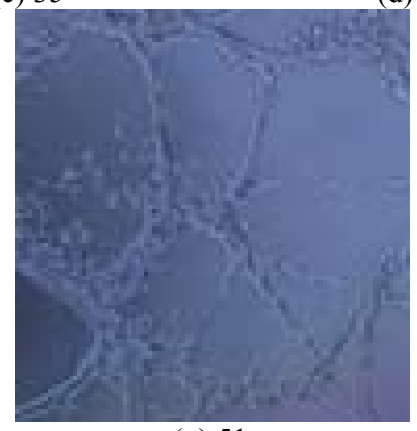

(g) 51

Fig. 11 Effects of 6S analogues on vascular lumen formation of HUVECs.

\section{Discussion}

Abnormalities of cell proliferation and differentiation are important reasons for canceration. As cancer develops, more nutrients will be needed to form microvessels. Efforts to develop anti-tumor drugs are mainly concentrated on the inhibition of tumor cell proliferation and angiogenesis. $6 \mathrm{~S}$ is an important active ingredient from ginger and believed to have anti-tumor activity, but not all tumor cells are sensitive to $6 \mathrm{~S}$. Cervical cancer and pancreatic cancer are highly malignant and by preliminary screening, we found that $6 \mathrm{~S}$ significantly inhibited the proliferation of cervical cancer cell line Hela and pancreatic cancer cells ASPC-1 and PANC-1. However, the $\mathrm{IC}_{50}$ of $6 \mathrm{~S}$ on the three cells was high. Therefore, $6 \mathrm{~S}$ analogues 
were further synthesized to assess the anti-proliferative effect. The result showed that compared with ASPC-1 and PANC-1 cells, Hela cells were more sensitive to $6 \mathrm{~S}$, indicating that different working mechanisms existed for 3 cell lines. Compounds 20 and 36 were more inhibitory on the proliferation of Hela cells than 6S, for ASPC-1 cells, compounds 44 displayed superior inhibitory performance, for PANC-1 cells, compounds 20, 44 exhibited superior inhibitory performance.

\section{Conclusions}

In this paper, we describe an efficient process to synthesize $6 \mathrm{~S}$ and analogues through 4-step reactions. In vitro anti-tumor activities test, some of the above analogues showed a strong potential for cancer therapy.

\section{Acknowledgments}

This research work was supported by the National Natural Science Foundation of China (NO. 81402816).

\section{References}

[1] Parkin, D. M., Bray, F., Ferlay, J., et al. 2001 "Estimating the World Cancer Burden: Globocan 2000." Int. J. Cancer 94 (2): 153-6.

[2] World Health Organization. Section of cancer information [DB/OL]. Globocan 2008.

[3] Kanavos, P. 2006. "The Rising Burden of Cancer in the Developing World.” Ann. Oncol 17 (Suppl 8): i15-23.

[4] Dong, Z. W. 2002. "The Goal of Tumor Treatment and Prevention in the New Century." Chinese Journal of Oncologyl 2002 (03): 107-8.

[5] Ling, H., Yang, H., Tan, S. H., et al. 2010. "6-Shogaol, an Active Constituent of Ginger, Inhibits Breast Cancer Cell Invasion by Reducing Matrix Metalloproteinase-9 Expression via Blockade of Nuclear Factor- $\kappa \mathrm{B}$ Activation.” Br. J. Pharmcol. 161 (8): 1763-77.

[6] Chen, C. Y., Yang, Y. H., and Kuo, S. Y. 2010. "Effect of [6]-Shogaol on Cytosolic $\mathrm{Ca}^{2+}$ Levels and Proliferation in Human Oral Cancer Cells (OC2)." J. Nat. Prod. 73 (8): 1370-4.

[7] Weng, C. J., Wu, C. F., Huang, H. W., et al. 2010. "Anti-invasion Effects of 6-Shogaol and 6-Gingerol, Two Active Components in Ginger, on Human Hepatocarcinoma Cells.” Mol. Nutr. Food Res. 54 (11):
1618-27.

[8] Hung, J. Y., Hsu, Y. L., Li, C. T., et al. 2009. "6-Shogaol, an Active Constituent of Dietary Ginger, Induces Autophagy by Inhibiting the AKT/mTOR Pathway in Human Non-small Cell Lung Cancer A549 Cells." J. Agric. Food. Chem. 57 (20): 9809-16.

[9] Pan, M. H., Hsieh, M. C., Kuo, J. M., et al. 2008. "6-Shogaol Induces Apoptosis in Human Colorectal Carcinoma Cells via ROS Production, Caspase Activation, and GADD 153 Expression." Mol. Nutr. Food. Res. 52 (5): 527-37.

[10] Chen, C. Y., Liu, T. Z., Liu, Y. W., et al. 2007. "6-Shogaol (Alkanone from Ginger) Induces Apoptotic Cell Death of Human Hepatoma p53 Mutant Mahlavu Subline via an Oxidative Stress-Mediated Caspase-Dependent Mechanism." J. Agric. Food. Chem. 55 (3): 948-54.

[11] Liu, Q., Peng, Y. B., Zhou, P., Qi, L. W., Zhang, M., Gao, N., Liu, E. H., and Li, P. 2013. "6-Shogaol Induces Apoptosis in Human Leukemia Cells through a Process Involving Caspase-Mediated Cleavage of eIF2 $\alpha . " \mathrm{Mol}$ Cancer 12: 135-8.

[12] Banno, K., and Mukaiyama, T. 1976. "A New Synthesis of the Pungent Principles of Ginger Zingerone, Gingerol and Shogaol." Bull. Chem. Society of Japan 49 (5): 1453-4.

[13] Kim, D. S. H. L., and Kim, J. Y. 2004. "Sidechain Length Is Important for Shogaols in Protecting Neurona Cells from Beta-Amyloid Insult." Bio. Med. Chem. Lett. 14 (5): $1287-9$.

[14] Vig; B., and Sharma, S. 1990. Indian Journal of Chemistry - Section B Organic Chemistry Including Medicinal Chemistry 29 (3): 284-6.

[15] Mase, N., Kitagawa, N., and Takabe, K. 2010. "Protection-, Salt-, and Metal-Free Syntheses of [n]-Shogaols by Use of Dimethylammonium Dimethyl Carbamate (DIMCARB) without Protecting Groups." Synlett. 1: 93-6.

[16] Denniff, P., Macleod, I., and Whiting, D. A. 1981. "Syntheses of the $\left(^{*}\right)-[\mathrm{n}]$-Gingerols (Pungent Principles of Ginger) and Related Compounds through Regioselective Aldol Condensations: Relative Pungency Assays." J.C.S. Perkin 1: 82-7.

[17] Nobuharu, K., Yasumasa, H., and Takayuki, S. 1984. "New Methods and Reagents Inorganic Synthesis 44: A New General Efficient Synthesis of Gingerols and Relatives through Direct C-Acylation Using Diethyl Phosphorocyanidate (DEPC)." Chemical \& Pharmaceutical Bulletin 32 (4): 1679-82.

[18] Awasthia, S., Pandyab, U., Singhala, S. S., Linc, J. T., Thiviyanathanb, V., Seifert, W. E., Awasthib, Y. C., and Ansarib, G. A. S. 2000. "Curcumin-Glutathione 
Interactions and the Role of Human Glutathione S-Transferase P1-1.” Chemico-Biological Interactions 128 (1): 19-38.

[19] Ishiguroa, K., Ando, T., Watanabe, O., and Goto, H. 2008.
"Specific Reaction of Alpha, Beta-Unsaturated Carbonyl Compounds Such as 6-Shogaol with Sulfhydryl Groups in Tubulin Leading to Microtubule Damage.” FEBS Letters 582 (23): 3531-6.

\section{Supplementary data}<smiles>CCCCCCCCC/C=C/C(=O)CCc1ccc(O)c(OC)c1</smiles>

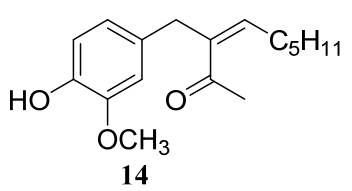

1: ${ }^{1} \mathrm{H}-\mathrm{NMR}\left(\mathrm{CDCl}_{3}, 500 \mathrm{MHz}\right): 6.83, \mathrm{~m}, 1 \mathrm{H} ; 6.77, \mathrm{~s}, 1 \mathrm{H} ; 6.68, \mathrm{~d}(J=8.0), 1 \mathrm{H} ; 6.61, \mathrm{~d}(J=7.0), 1 \mathrm{H} ; 6.10, \mathrm{~d}(J=7.0), 1 \mathrm{H} ; 15.1$; 3.82, s, 3H; 2.79-2 .88, m, 4H; 2.21 dd $(J=15.6,7.0), 2 \mathrm{H} ; 1.46, \mathrm{~m}, 2 \mathrm{H} ; 1.31, \mathrm{~m}, 4 \mathrm{H} ; 0.91, \mathrm{t}(\mathrm{J}=7.2), 3 \mathrm{H} ; \mathrm{MS}(\mathrm{m} / \mathrm{z}):[\mathrm{M}+\mathrm{H}]^{+} 277$.

14: ${ }^{1} \mathrm{H}-\mathrm{NMR}\left(\mathrm{CDCl}_{3}, 500 \mathrm{MHz}\right) 6.89$ t (J=7.5), 1H; 6.69, s, 1H; 6.65, d(J=2.0), 1H; 6.53, d(J=7.0), 1H; 3.78, s, 3H; 2.34 , m, 2H; $2.31, \mathrm{~s}, 3 \mathrm{H} ; 1.46, \mathrm{t}(J=2), 2 \mathrm{H} ; 1.31, \mathrm{~m}, 4 \mathrm{H} ; 0.88, \mathrm{t}(J=2), 3 \mathrm{H} . \mathrm{MS}(\mathrm{m} / \mathrm{z}):[\mathrm{M}+\mathrm{H}]^{+} 277$.<smiles>[R]C=CC(=O)CCc1ccc(O)c(OC)c1</smiles><smiles>[R]C#CC1CCCC1</smiles><smiles>[R2]#CC1CCCCC1C#[R]</smiles>

19: H-NMR ( $\left.\mathrm{CDCl}_{3}, 500 \mathrm{MHz}\right)$ : 0.63, m, 2H; 0.97, m, 2H; 1.50, m, 1H; 2.75-2.87,m, 4H;3.87, s, 3H; 6.20, d(J=15.5), 1H; 6.27, $\mathrm{d}(\mathrm{J}=10), 1 \mathrm{H}$; 6.66-6.83, m, 3H; ${ }^{13} \mathrm{C}-\mathrm{NMR}\left(\mathrm{CDCl}_{3}, 75 \mathrm{MHz}\right)$ : 8.9, 8.9, 14.6, 29.8, 42.1, 55.7, 111.0, 114.0, 120.6, 127.1, 133.1, 146.3, 150.1, 152.8, 198.8. HRMS (m/z): [M-H] calcd. for $\mathrm{C}_{15} \mathrm{H}_{17} \mathrm{O}_{3}$, 245.1183; found, 245.1179.

20: H-NMR ( $\left.\mathrm{CDCl}_{3}, 500 \mathrm{MHz}\right): 1.85-2.0, \mathrm{~m}, 6 \mathrm{H} ; 2.73$, d(J=7.5), 1H, 2.80-2.86, m, 4H; 3.86, s, 3H; 6.00, dd( $\left.J=15.9,1.2\right), 1 \mathrm{H}$; 6.65-6.83, m, 4H; ${ }^{13} \mathrm{C}-\mathrm{NMR}\left(\mathrm{CDCl}_{3}, 75 \mathrm{MHz}\right)$ : 19.0, 28.9, 28.9, 30.7, 35.7, 42.0, 55.7, 111.1, 114.0, 120.5, 127.8, 131.8, 143.6, 146.3, 149.0, 199.5. HRMS (m/z): [M-H] calcd. for $\mathrm{C}_{16} \mathrm{H}_{19} \mathrm{O}_{3}$, 259.1304; found, 259.1311.

21: H-NMR (CDCl, 500 MHz): 1.35, m, 2H; 1.61, m, 2H; 1.65, m, 2H; 1.82, m, 2H; 2.55, m, 1H; 2.88, m, 4H; 3.87, s, 3H; 6.06, $\mathrm{d}(\mathrm{J}=15.6), 1 \mathrm{H} ;$ 6.67-6.83, m, 4H; ${ }^{13} \mathrm{C}-\mathrm{NMR}\left(\mathrm{CDCl}_{3}, 75 \mathrm{MHz}\right)$ : 25.2, 25.6, 29.8, 32.4, 33.2, 41.9, 43.0, 55.7, 111.0, 114.2, 120.6 , 128.3, 133.1, 143.6, 146.3, 151.9, 200.0. HRMS (m/z): [M-H] calcd. for $\mathrm{C}_{17} \mathrm{H}_{21} \mathrm{O}_{3}$, 273.1496; found, 273.1500.

22: H-NMR ( $\left.\mathrm{CDCl}_{3}, 500 \mathrm{MHz}\right)$ : 1.18-1.32, m, 5H; 1.65-1.75, m, 5H; 2.10, m, 1 H; 2.82, m, 4H; 3.86, s, 3H; 6.12, dd(J=15.6, 1.5), 1H; 6.66-6.82, m, 4H; ${ }^{13} \mathrm{C}-\mathrm{NMR}\left(\mathrm{CDCl}_{3}, 75 \mathrm{MHz}\right)$ : 25.5, 25.7, 29.8, 31.6, 31.6, 40.4, 41.8, 55.7, 111.1, 114.2, 120.6, 133.0, 143.8, 146.3, 152.5, 200.2. HRMS (m/z): [M-H] calcd. for $\mathrm{C}_{18} \mathrm{H}_{23} \mathrm{O}_{3}$, 287.1653; found, 287.1649.<smiles>[R]C=CC(=O)CCc1ccc(O)c(OC)c1</smiles>

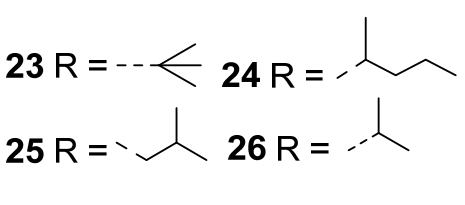

23: H-NMR (CDCl 3 , $500 \mathrm{MHz}): 1.06$, s, 9H; 2.86, s, 4H; 6.00, d(J=16.2), 2H; 6.67-6.84, m, 3H; ${ }^{13} \mathrm{C}-\mathrm{NMR}\left(\mathrm{CDCl}_{3}, 75 \mathrm{MHz}\right): 28.5$, 28.5, 28.5, 29.8, 33.6, 42.1, 55.8, 111.1, 114.3, 120.7, 125.4, 133.1, 143.8, 146.4, 157.2, 200.3. HRMS (m/z): [M-H] calcd. for $\mathrm{C}_{18} \mathrm{H}_{17} \mathrm{O}_{3}$, 281.1183; found, 281.1182 
25: H-NMR ( $\left.\mathrm{CDCl}_{3}, 500 \mathrm{MHz}\right)$ : 0.91, d(J=6.6), 6H; 1.73, m, 1H; 2.08, d(J=7.5), 2H; 2.85, m, 2H; 5.52, b.s., 1H; 6.08, dt(J=15.9, 1.2,), $1 \mathrm{H} ;$ 6.66-6.84, m, 4H; ${ }^{13} \mathrm{C}-\mathrm{NMR}\left(\mathrm{CDCl}_{3}, 75 \mathrm{MHz}\right)$ :22.2, 22.2, 27.8, 29.8, 41.6, 41.9,55.7, 111.1, 114.2, 120.7, 128.4, 133.1, 143. 8, 146.5, 153.0, 200.0. HRMS (m/z): [M-H] calcd. for $\mathrm{C}_{17} \mathrm{H}_{23} \mathrm{O}_{3}, 275.1653$; found, 275.1649.

26: H-NMR (CDCl 3 , 500 MHz): 1.05, d(J=6.9), 6H; 2.43, m,1H; 2.85, m, 4H; 3.87, s, 3H; 5.49, s, 1H; 6.04, dd(J=15.9, 1.2), 1H; 6.67-6.84, m, 4H; ${ }^{13} \mathrm{C}-\mathrm{NMR}\left(\mathrm{CDCl}_{3}, 75 \mathrm{MHz}\right)$ : 21.2, 21.2, 29.8, 31.1, 42.0, 55.8, 111.1, 114.9, 120.7, 127.5, 133.2, 143.8, 146.4, 153.7, 200.1. HRMS (m/z): [M-H] calcd. for $\mathrm{C}_{15} \mathrm{H}_{19} \mathrm{O}_{3}$, 247.1340; found, 247.1340.

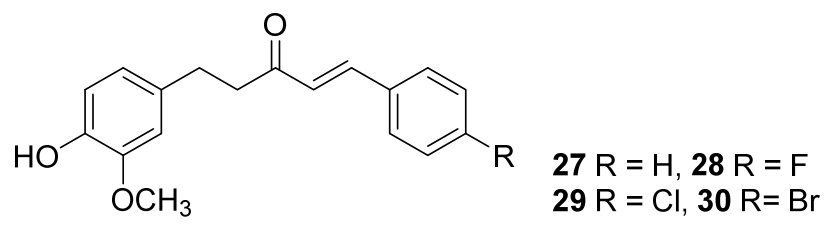

27: H-NMR(CDCl 3 , $500 \mathrm{MHz}): 2.94, \mathrm{~m}, 4 \mathrm{H} ; 3.87$, s, 3H; 5.51, bs, $1 \mathrm{H} ; 6$ 6,65-6.85, m, 4H; 7.37-7.56, m,6H; ${ }^{13} \mathrm{C}-\mathrm{NMR}\left(\mathrm{CDCl}_{3}, 75\right.$ MHz): 29.8, 42.7, 55.8, 111.1, 114.3, 120.8, 126.1, 128,2, 128.2, 128.9, 128.9, 130.4, 133.0, 133.0, 134.4, 142.7, 143.9, 146.4 , 199.5. HRMS (m/z): [M-H] calcd. for $\mathrm{C}_{18} \mathrm{H}_{17} \mathrm{O}_{3}, 281.1183$; found, 281.1182.

28: H-NMR CDCl 3 , 500 MHz): 2.94, m, 4H; 3.87, s, 3H; 5.46, bs, $1 \mathrm{H} ; 6.67-6.84, \mathrm{~m}, 4 \mathrm{H} ; 7.34,-7.49, \mathrm{~m}, 5 \mathrm{H} ;{ }^{13} \mathrm{C}-\mathrm{NMR}\left(\mathrm{CDCl}_{3}, 75\right.$ MHz): 29.8, 42.9, 55.8, 111.1, 114.3,115.9, 116.2, 120.8, 125.8, 125.8, 130.0,130.1, 133.0, 141.3, 143.9, 146.4,165.5, 199.2, HRMS (m/z): [M-H] calcd. for $\mathrm{C}_{18} \mathrm{H}_{16} \mathrm{O}_{3} \mathrm{~F}, 299.1089$; found, 299.1087.

29: H-NMR ( $\left.\mathrm{CDCl}_{3}, 500 \mathrm{MHz}\right): 2.94, \mathrm{~m}, 4 \mathrm{H} ; 3.87, \mathrm{~s}, 3 \mathrm{H} ; 5.46$, bs, $1 \mathrm{H} ; 6.68-6.73, \mathrm{~m}, 3 \mathrm{H} ; 1 \mathrm{H} ; 6.83, \mathrm{~d}(J=8), 1 \mathrm{H} ; 7.37, \mathrm{~d}(J=8.5), 2 \mathrm{H}$; 7.46, d(J=16), 1H; 7.52, d(J=8.5), 2H; ${ }^{13} \mathrm{C}-\mathrm{NMR}\left(\mathrm{CDCl}_{3}, 75 \mathrm{MHz}\right): 29.7,42.9,55.8,111.1,114.3,120.7,126.4,129.1,129.1,129.3$, 129.3, 131.0, 132.9, 135.2, 141.1, 143.9, 146.4, 199.2. HRMS (m/z): [M-H] calcd. for $\mathrm{C}_{18} \mathrm{H}_{16} \mathrm{O}_{3} \mathrm{Cl}, 315.0793$; found, 315.0800.

30: H-NMR ( $\left.\mathrm{CDCl}_{3}, 500 \mathrm{MHz}\right)$ : 2.94, m, 4H; 3.87, s, 3H; 5.45, b.s., 1H; 6.67-6.73, m, 3H; 6.83, d(J=8), 1H; 7.36, d(J=8), 2H; 7.44-7.49, m, 3H; ${ }^{13} \mathrm{C}-\mathrm{NMR}\left(\mathrm{CDCl}_{3}, 75 \mathrm{MHz}\right)$ : 29.8, 42.9, 55.8, 111.1, 114.3 120.8, 124.7, 126.6, 129.6,129.9 132.1,132.1, 133.0, 133.7, 141.2, 143.9, 146.4, 199.2. HRMS (m/z): [M-H] calcd. for $\mathrm{C}_{18} \mathrm{H}_{16} \mathrm{O}_{3} \mathrm{Br}$, 359.0300; found, 359.0300.

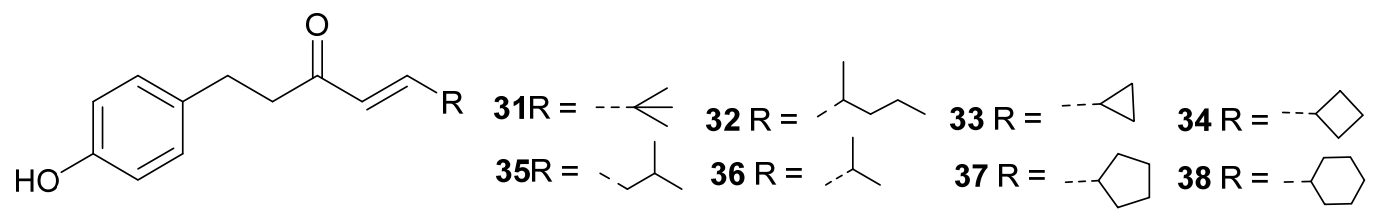

31: H-NMR (CDCl, $500 \mathrm{MHz}): 1.05, \mathrm{~s}, 9 \mathrm{H} ; 2.86, \mathrm{~s}, 4 \mathrm{H} ; 5.28, \mathrm{~s}, 1 \mathrm{H} ; 6.00, \mathrm{~d}(J=15.9), 1 \mathrm{H} ; 6.75-6.84, \mathrm{~m}, 3 \mathrm{H} ; 7.03, \mathrm{~d}(J=8.4), 1 \mathrm{H}$; ${ }^{13} \mathrm{C}-\mathrm{NMR}\left(\mathrm{CDCl}_{3}, 75 \mathrm{MHz}\right)$ : 28.5, 28.5, 28.5, 29.4, 33.7, 42.0, 115.3, 115.3, 125.3, 132.6, 132.6, 154.3,158.0, 201.4. HRMS (m/z): [M-H] calcd. for $\mathrm{C}_{15} \mathrm{H}_{19} \mathrm{O}_{2}, 231.1391$; found, 231.1388 .

32: H-NMR ( $\left.\mathrm{CDCl}_{3}, 500 \mathrm{MHz}\right): 0.87, \mathrm{t}(J=6.6), 3 \mathrm{H} ; 1.14, \mathrm{~d}(J=6.6), 3 \mathrm{H} ; 1.18-1.40, \mathrm{~m}, 4 \mathrm{H} ; 2.85, \mathrm{~m}, 4 \mathrm{H} ; 6.06, \mathrm{~d}(J=15.9), 1 \mathrm{H}$; 6.68-6.78, m, 3H; 7.03, d(J= 8.4), 2H; ${ }^{13} \mathrm{C}-\mathrm{NMR}\left(\mathrm{CDCl}_{3}, 75 \mathrm{MHz}\right): 13.8,19.2,120.2,29.3,36.4,38.0,41.7,115.3,115.3,128.3$, 129.2, 129.2, 132.3, 153.8, 154.5, 201.2. HRMS (m/z): [M-H] calcd. for $\mathrm{C}_{16} \mathrm{H}_{21} \mathrm{O}_{2}$, 245.1454; found, 245.1547.

33: H-NMR(CDCl, 500 MHz): 0.90, d(J=6.9), 6H; 1.75, m, 1H; 2.08, t (J=7.2), 2H; 2.84, m, 4H; 6.13, d(J=15.9), 1H; 6.68-7.03, m, 5H; ${ }^{13} \mathrm{C}-\mathrm{NMR}\left(\mathrm{CDCl}_{3}, 75 \mathrm{MHz}\right)$ : 22.2, 22.2, 27.7, 29.4, 41.6, 41.8, 115.2, 115.2, 129.1, 129.1, 131.1, 132.5, 147.4, $154.1,200.5$. HRMS (m/z): [M-H] calcd. for $\mathrm{C}_{15} \mathrm{H}_{19} \mathrm{O}_{2}, 231.1391$; found, 231.1389.

34: H-NMR(CDCl, $500 \mathrm{MHz}): 1.03, \mathrm{~d}(J=6.9), 6 \mathrm{H} ; 2.47, \mathrm{~m}, 1 \mathrm{H} ; 2.78-2.85, \mathrm{~m}, 4 \mathrm{H} ; 6.05, \mathrm{~d}(J=15.9), 1 \mathrm{H} ; 6.70-7.03, \mathrm{~m}, 5 \mathrm{H}$; ${ }^{13} \mathrm{C}-\mathrm{NMR}\left(\mathrm{CDCl}_{3}, 75 \mathrm{MHz}\right)$ : 21.1, 21.1, 29.4, 30.1, 42.9, 115.3, 115.3, 127.3, 129.3, 129.3, 132.5, 152.1, 154.7, 201.5. HRMS (m/z): [M-H] ${ }^{-}$calcd. for $\mathrm{C}_{14} \mathrm{H}_{17} \mathrm{O}_{2}, 217.1234$; found, 217.1234. 
35: H-NMR(CDCl, 500 MHz): 0.55-0.67, m, 2H; 0.92, m, 2H; 1.54, m, 1H; 2.62-2.90, m, 4H; 6.18-6.35, m, 2H; 6.75-7.08, m, 4H; ${ }^{13} \mathrm{C}-\mathrm{NMR}\left(\mathrm{CDCl}_{3}, 75 \mathrm{MHz}\right):$ 8.75, 8.75, 14.1, 29.4, 41.8, 115.3, 115.3, 126.9, 129.2, 129.2, 132.3, 154.0, 154.4, 200.2. HRMS (m/z): [M-H] calcd. for $\mathrm{C}_{14} \mathrm{H}_{17} \mathrm{O}_{2}, 215.1078$; found, 215.1076.

36: H-NMR(CDCl, 500 MHz): 1.81-1.98, m, 3H; 2.10-2.25, m, 3H; 2.84, m, 4H; 3.08, m, 1H; 6.02, d(J=15.9), 1H; 6.68-7.02, m, $5 \mathrm{H} ;{ }^{13} \mathrm{C}-\mathrm{NMR}\left(\mathrm{CDCl}_{3}, 75 \mathrm{MHz}\right): 18.2,27.2,27.2,28.9,29.3,37.7,41.8,115.2,115.2,127.7,129.8,129.8,132.5,151.8,154.3$, 201.3. HRMS (m/z): [M-H] $]^{-}$calcd. for $\mathrm{C}_{15} \mathrm{H}_{17} \mathrm{O}_{2}$, 229.1234; found, 21235.

37: H-NMR(CDCl 3 , 500 MHz):1.36-1.40, m, 2H; 1.52-1.64, m, 2H; 1.65-1.90, m, 2H; 2.10, m, 1H; 2.84, m, 4H; 6.12, d(J=15.9), 1H; 6.67-7.02, m, 5H; ${ }^{13} \mathrm{C}-\mathrm{NMR}\left(\mathrm{CDCl}_{3}, 75 \mathrm{MHz}\right)$ : 25.2, 25.2, 29.4, 32.3, 32.3, 41.7, 43.9, 115.2, 115.2, 128.1, 129.2, 129.2, 132.4, 153.0, 154.3, 201.4. HRMS (m/z): [M-H] ${ }^{-}$calcd. for $\mathrm{C}_{16} \mathrm{H}_{19} \mathrm{O}_{2}$, 243.1391 found, 243.1390.

38: H-NMR(CDCl 3 , $500 \mathrm{MHz})$ : 1.04-1.34, m, 4H; 1.64-1.74, m, 4H; 2.09, m, 1H; 6.04, d(J=15.9), 1H; 6.71-7.03, m, 5H; ${ }^{13} \mathrm{C}-\mathrm{NMR}\left(\mathrm{CDCl}_{3}, 75 \mathrm{MHz}\right): 25.5,25.5,25.7,29.3,31.5,31.5,40.5,41.7,111.3,115.3,127.6,129.2,129.2,132.5,153.5,154.3$, 201.5. HRMS (m/z): [M-H] $]^{-}$calcd. for $\mathrm{C}_{17} \mathrm{H}_{21} \mathrm{O}_{2}, 257.1547$; found, 257.1544.<smiles>[R]C=CC(=O)CCc1cccc(O)c1</smiles>

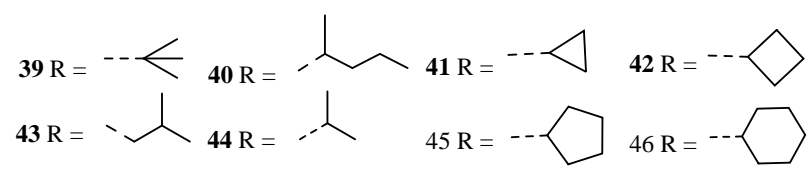

39: H-NMR(CDCl, 500 MHz): 1.05, s, 9H; 2.88, s, 4H; 6.00, d(J=16.2), 1H; 6.68-6.75, m, 3H; 6.81, d(J=16.2), 1H; 7.12, t(J=8.1), 1H; ${ }^{13} \mathrm{C}-\mathrm{NMR}\left(\mathrm{CDCl}_{3}, 75 \mathrm{MHz}\right)$ : 28.6, 28.6, 28.6, 30.0, 33.7, 41.5, 113.2, 115.4, 120.3, 125.3, 129.5, 142.8, 156.0, $158.1,201.2$. HRMS (m/z): [M-H] ${ }^{-}$calcd. for $\mathrm{C}_{15} \mathrm{H}_{19} \mathrm{O}_{2}$, 231.1394; found, 231.1391.

40: H-NMR(CDCl $3,500 \mathrm{MHz}): 0.85, \mathrm{t}(J=6.3), 3 \mathrm{H} ; 1.01, \mathrm{~d}(J=6.6), 3 \mathrm{H} ; 1.26-1.35, \mathrm{~m}, 4 \mathrm{H} ; 2.28, \mathrm{~m}, 1 \mathrm{H} ; 2.80, \mathrm{~m}, 2 \mathrm{H} ; 6.06$, $\mathrm{d}(J=16.2), 1 \mathrm{H} ; 6.68-6.76, \mathrm{~m}, 4 \mathrm{H} ; 7.11, \mathrm{t}(J=8.1), 1 \mathrm{H} ;{ }^{13} \mathrm{C}-\mathrm{NMR}\left(\mathrm{CDCl}_{3}, 75 \mathrm{MHz}\right): 13.6,19.2,20.2,30.0,36.5,38.1,41.3,113.2$, 115.2, 120.2, 128.3, 129.5, 142.7, 154.1, 156.1, 201.1. HRMS (m/z): [M-H] calcd. for $\mathrm{C}_{16} \mathrm{H}_{21} \mathrm{O}_{2}$, 245.1454; found, 245.1543.

41: H-NMR(CDCl 3 , 500 MHz): 0.91, d(J=6.6), 6H; 1.62-1.82, m, 4H; 2.86, m, 4H; 5.27, s, 1H; 6.14, d(J=15.9), 1H; 6.64-7.12, m, 5H; ${ }^{13} \mathrm{C}-\mathrm{NMR}\left(\mathrm{CDCl}_{3}, 75 \mathrm{MHz}\right)$ : 22.2, 22.2, 27.7, 30.0, 41.3, 41.6, 112.9, 115.3, 120.1, 129.4, 131.1, 140.9, 142.6, $156.1,200.3$. HRMS (m/z): [M-H] calcd. for $\mathrm{C}_{15} \mathrm{H}_{19} \mathrm{O}_{2}, 231.1391$; found, 231.1389.

42: H-NMR(CDCl 3 , $500 \mathrm{MHz}): 1.03, \mathrm{~d}(J=6.9), 6 \mathrm{H} ; 2.42, \mathrm{~m}, 1 \mathrm{H} ; 2.86, \mathrm{~m}, 4 \mathrm{H} ; 6.04, \mathrm{~d}(J=15.9), 1 \mathrm{H} ; 6.56-7.25 \mathrm{~m}, 5 \mathrm{H} ;{ }^{13} \mathrm{C}-\mathrm{NMR}$ $\left(\mathrm{CDCl}_{3}, 75 \mathrm{MHz}\right): 21.1,21.1,30.0,31.1,41.3,113.0,115.3,120.1,127.3,129.3,142.6,154.8,156.1,201.3 . \mathrm{HRMS}(\mathrm{m} / \mathrm{z})$ : [M-H] calcd. for $\mathrm{C}_{14} \mathrm{H}_{17} \mathrm{O}_{2}$, 217.1234; found, 217.1231.

43: H-NMR(CDCl, $500 \mathrm{MHz})$ : 0.61, m, 4H; 0.95, m, 1H; 2.83, m, 4H; 6.14-6.35, m, 2H; 6.65-6.77, m, 2H; 7.04-726, m, 2H; ${ }^{13} \mathrm{C}-\mathrm{NMR}\left(\mathrm{CDCl}_{3}, 75 \mathrm{MHz}\right):$ 9.05, 9.05, 14.7, 30.0, 41.4, 112.9, 115.3, 120.0, 126.9, 129.4, 142.6, 154.0, 156.4, 199.9. HRMS (m/z): [M-H] calcd. for $\mathrm{C}_{14} \mathrm{H}_{15} \mathrm{O}_{2}$, 215.1074; found, 215.1078.

44: H-NMR(CDCl $3,500 \mathrm{MHz}): 1.82-2.00, \mathrm{~m}, 6 \mathrm{H} ; 2.86, \mathrm{~m}, 3 \mathrm{H} ; 3.11,3.40, \mathrm{~m}, 1 \mathrm{H} ; 6.00, \mathrm{~d}(\mathrm{~J}=15.9), 1 \mathrm{H} ; 6.23-7.14, \mathrm{~m}, 5 \mathrm{H}$; ${ }^{13} \mathrm{C}-\mathrm{NMR}\left(\mathrm{CDCl}_{3}, 75 \mathrm{MHz}\right)$ : 18.5, 30.0, 30.0, 31.0, 37.9, 41.4, 113.1, 115.3, 120.3, 127.7, 129.5, 150.3, 151.8, 156.1, 200.9. HRMS (m/z): [M-H] calcd. for $\mathrm{C}_{15} \mathrm{H}_{17} \mathrm{O}_{2}, 229.1234$; found, 229.1233.

45: H-NMR(CDCl, $500 \mathrm{MHz}):$ 1.35, m, 2H; 1.62, m, 2H; 1.83, m, 2H; 2.86, m, 4H; 5.28, s, 1H; 6.68-6.84, m, 4H; 7.13, t (J=8.1), $1 \mathrm{H} ;{ }^{13} \mathrm{C}-\mathrm{NMR}\left(\mathrm{CDCl}_{3}, 75 \mathrm{MHz}\right)$ : 25.5, 25.5, 29.8, 32.3, 32.7, 41.3, 43.0, 113.1, 115.3, 120.0, 121.1, 129.4, 142.1, 151.1, 156.2, 200.7. HRMS ( $\mathrm{m} / \mathrm{z})$ : [M-H] ${ }^{-}$calcd. for $\mathrm{C}_{16} \mathrm{H}_{19} \mathrm{O}_{2}, 243.1391$; found, 243.1389.

46: H-NMR(CDCl 3 , $500 \mathrm{MHz}): 1.14-1.42, \mathrm{~m}, 6 \mathrm{H} ; 1.56-1.78, \mathrm{~m}, 4 \mathrm{H} ; 2.10, \mathrm{~m}, 1 \mathrm{H} ; 2.86, \mathrm{~m}, 4 \mathrm{H} ; 6.04, \mathrm{dd}(J=15.9,1.2), 1 \mathrm{H}$; 6.67-6.75, m, 4H; 7.12, m, 1H; ${ }^{13} \mathrm{C}-\mathrm{NMR}\left(\mathrm{CDCl}_{3}, 75 \mathrm{MHz}\right)$ : 25.5, 25.2, 25.6, 29.9, 31.5, 31.5, 40.5, 41.2, 113.0, 115.3, 120.2, 127.6, 129.4, 142.8, 150.7, 156.0, 200.9. HRMS (m/z): [M-H] calcd. for $\mathrm{C}_{17} \mathrm{H}_{21} \mathrm{O}_{2}$, 257.1547; found, 257.1548. 


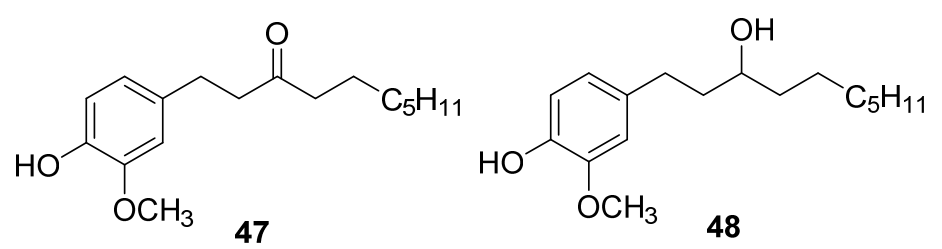

47: H-NMR(CDCl 3 , $500 \mathrm{MHz}): 0.85, \mathrm{t}(J=6.9), 3 \mathrm{H} ; 1.25, \mathrm{bs}, 8 \mathrm{H} ; 1.57, \mathrm{~m}, 2 \mathrm{H} ; 2.36, \mathrm{t}(J=7.5), 2 \mathrm{H} ; 2.66-2.85, \mathrm{~m}, 4 \mathrm{H} ; 3.86, \mathrm{~s}, 3 \mathrm{H}$; 6.64-6.83, m, $3 \mathrm{H}$.

48: $\mathrm{H}-\mathrm{NMR}\left(\mathrm{CDCl}_{3}, 500 \mathrm{MHz}\right): 0.89, \mathrm{t}(\mathrm{J}=6.5), 3 \mathrm{H} ; 1.25, \mathrm{bs}, 10 \mathrm{H} ; 1.45, \mathrm{~m}, 4 \mathrm{H} ; 1.74, \mathrm{~m}, 2 \mathrm{H} ; 2.60,2.72, \mathrm{~m}, 2 \mathrm{H} ; 3.61, \mathrm{~s} 1 \mathrm{H} ; 3.87, \mathrm{~s}$, $3 \mathrm{H} ; 6.68-6.70, \mathrm{~m}, 2 \mathrm{H} ; 6.82, \mathrm{~d}(\mathrm{~J}=8), 1 \mathrm{H}$.

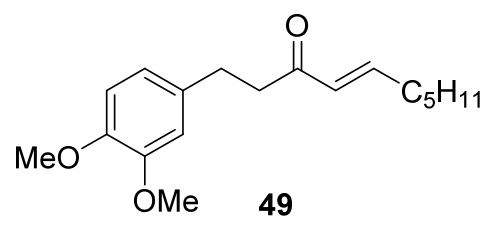

49: $\mathrm{H}-\mathrm{NMR}\left(\mathrm{CDCl}_{3}, 500 \mathrm{MHz}\right): 0.88, \mathrm{t}(J=9.6), 3 \mathrm{H} ; 1.25-1.34, \mathrm{~m}, 6 \mathrm{H} ; 2.20, \mathrm{~m}, 2 \mathrm{H} ; 2.85, \mathrm{~m}, 4 \mathrm{H} ; 3.83,3.85, \mathrm{~s}$, 各 $3 \mathrm{H} ; 6.14, \mathrm{dt}(J=$ $16.5,1.5), 1 \mathrm{H} ; 6.67-6.87, \mathrm{~m}, 4 \mathrm{H}$. 